\title{
The sorcery of gender: sex, death and difference in East Java, Indonesia ${ }^{1}$
}

\author{
Konstantinos Retsikas
}

\begin{abstract}
Drawing on ethnographic material from East Java, Indonesia, this article examines the intersections of sorcery and gender and suggests that sorcery is a form of exchange, which, as well as inducing misfortune, pain and death, evinces gender. Key here are the invocation and inversion of marriage transactions and wedding rituals, and an underlying conception of the person as inherently androgynous. The article also calls for sorcery and other manifestations of violence to be moved away from the margins and towards the centre of anthropological descriptions of Javanese sociality.
\end{abstract}

Keywords: sorcery; gender; sex; agency; affectivity; Java

Author details: The author is Lecturer in the Anthropology of South East Asia at the School of Oriental and African Studies, University of London, Thornhaugh Street, Russell Square, London WC1H 0XG, UK. E-mail: kr1@soas.ac.uk; kostasretsikas@yahoo.com.

'There is in truth no male no female.'?

In a recent interview, Didik Nini Thowok, the famous Javanese transvestite dancer, said of his performances:

'For me, I never think about who is behind the mask. I only see the character in the mask. . When a woman dances the male mask, she is transformed - it is mystical. And when a man dresses up as a woman, in bedhaya, we don't always recognise that the dancer is male - it is mystical. He, too, is transformed. I believe a better term [than transgender] is “mystical gender". I plan using this term.' (Ross, 2005, p 226)

1 This article is based on 18 months of fieldwork from September 1998 to March 2000. The paper is dedicated to Mas Bukhari (pseudonym). I alone am responsible for all errors and misinterpretations.

2 From Suluk Lonthang, an early nineteenth century Sufi song from Java, as translated by Florida (1996, p 208). 
Didik refers here to his own work as a male dancer performing female roles, a practice that both continues and advances 'traditional' Javanese court dance practices according to which the gender of the performer and the character portrayed do not always coincide (see also Soedarsono, 1969). Such cross-gender dances, as well as gender-crossing ones in which the gender of the character changes in certain key episodes of the story, manifest an understanding of gender as unstable and always in motion. In this article, I claim that this condition of mobility and mutability that Didik describes as 'mystical' is informed and facilitated by a concept of the person as inherently androgynous. This androgyny is best exemplified, but not necessarily limited in Didik's status as a banci, a transvestite, a plural combination of femininity and masculinity. In the context of dance performances, furthermore, both the wearing of a mask and the donning of a dress as objectifications of the gendered other are held as efficacious enough in inducing an oscillatory movement from male to female, or female to male.

Didik's and other similar performances share a strong affinity with current Western academic attempts at getting away from thinking in terms of fixed gendered categories. With respect to the latter, such an attempt has been marked by a proliferation of analytical modalities ranging from discourse analysis (Butler, 1990) and queer and sexualities studies (Warner, 2000; Boellstorff, 2007) that emphasize the ways that individuals 'take up gendered subject positions through engagement with multiple discourses on gender' (Moore, 1994, p 56) and place a premium on the associated politics, to others such as that of Strathern (1988) that are embedded within the theoretical horizons of ethno-sociology and regional synthesis. In this paper, I am particularly concerned with Strathern's dissociation of gendered subjects from gendered attributes and the introduction of the idea of personhood as a composite, androgynous entity. Writing with respect to Melanesia, Strathern argues that "being "male" or being "female" emerges as a holistic unitary state under particular circumstances. [. . .] each male or female form may be regarded as containing within it a suppressed composite identity; it is activated as androgyny transformed' (1988, p 14). To the extent that persons in Melanesia are thought of as a microcosm of social relations, they contain both male and female attributes. Such attributes allow persons to become gendered in singular form: that is, as male or female in specific contexts and as a result of entering into specific relations. This is how Strathern in her own particular way puts it: 'a dividual androgyne is rendered an individual in relation to a 
counterpart individual. An internal duality is externalised or elicited in the presence of a partner; what was "half" a person becomes "one" of a pair' (1988, p 15). In her scheme of things Melanesian, the eliciting cause is always the presence and actions of a social other, while the mechanism through which this elicitation is achieved and gender is made temporarily visible, rests on exchanges, including those of valuables as well as those of substance.

In this paper, I draw on ethnographic material from East Java, Indonesia, and I demonstrate that sorcery is a technology for the elicitation of gender, as well as for the inducing of death. Differently put, I claim that sorcery as envisaged in Java is a technique that, in order to achieve its desired outcome (that is, to bring about misfortune, illness and often death to the victim), seeks to en-gender it, first in masculine and then in feminine form. The en-gendering process itself rests on a series of exchanges involving two sets of actors: the sorcerer and his client; and the victim and the sorcerer's spirit-familiar. The gender of these actors takes alternate forms, while the exchanges that sorcery instigates rest on the evocation of marriage transactions. In this regard, Didik's comments of a 'mystical gender' in operation during masked performances acquire particular relevance. In the place of the mask, the sorcerer induces gender transformations through the employment of a set of macabre paraphernalia that includes effigies, spells and sacrifices. The anticipated transformations in this (as in Didik's case), I claim, are possible only because of an indigenous understanding of the person as androgynous.

My treatment of sorcery here is not limited to concerns regarding gender only, but extends to those of sociality. Although I do not see sociality in East Java as necessarily or by definition gendered, the deadly presencing of the other in oneself in sorcery practices carries certain implications for anthropological renditions of Javanese sociality as predicated on convivial harmony. Colonial and post-colonial descriptions of Javanese village life as orderly, peaceful and egalitarian, as unpacked by Newberry (2007) and Pemberton (1994), share an affinity with a long tradition of anthropological description. With a few notable exceptions, they all emphasize the aesthetics and ethics of convivial intimacy, mutual dependence and solidarity. Clifford Geertz, for example, while noting the presence of divisive social forces in 1950s Java, opted largely for highlighting the 'two points making for a moderation of religious conflict - tolerance based on "contextual relativism" and the growth of social mechanisms for a pluralistic non- 
syncretic form of social integration' (1960, p 373). Despite the massacres of the 1960s, this one-sided picture of Javanese life has continued to permeate both indigenous and subsequent Western accounts. In his encompassing Javanese Culture, the native anthropologist Koentjaraningrat (1989) describes the ritual of slametan as the ceremonial expression of the gotong royong [mutual assistance] ethic that serves to build and instil a sense of solidarity and equality among the ceremony's participants. More recently, Andrew Beatty has shown how Geertz's 'contextual relativism' is founded first on the ritual promotion of an ethos stressing common humanity over and above difference (1999) and a cognitive and affective scheme of 'changing places' and adopting the other's point of view (2002).

I do not claim this to be a false representation of Javanese society; quite the contrary. In a recent article, I have myself shown how on Java's east coast, 'the moral economy of intimacy', to borrow a term from Amazonian ethnography (see Overring and Passes, 2000; SantosGranero, 2007), has been integral in the transformation of the ethnic heterogeneity of the past into present similitude; and I have emphasized associated processes towards the domestication of alterity (Retsikas, 2007b). However, the truth remains that this picture is one-sided and that anthropological descriptions of convivial harmony need to be complemented by research into the symbolic economy of predation. The excursion into sorcery practices here serves this purpose too. I do not claim either that at the heart of Javanese sociality lies a dilemma between conviviality and predation. As Viveiros de Castro (1996) observes for Amazonia, the two modes do not refer to exclusive and formally opposed styles of sociality and/or frames of analysis. Rather, the two modes constantly invoke and elicit one another in the same way that masculinity is revealed by the eclipsing of femininity in one and the same androgynous person. After all, in times of need, my informants look to their kin, neighbours, friends and colleagues for support and comfort. Yet it is these same people who are also blamed for casting a spell when misfortune strikes.

\section{Agency and affect}

Alas Niser is situated at the southern edge of the city of Probolinggo in East Java. It is a collection of neighbourhoods [kampong], administered by different villages [desa]. Alas Niser's current population is made up of migrants and descendants of migrants from 
other places in Java and Madura (Retsikas, 2007b). These demographic movements were the result of the political and economic transformation of the area during colonial times, and have continued into the post-colonial period, though at a much slower pace. Today the inhabitants of Alas Niser identify themselves as neither Javanese nor Madurese, but as 'mixed people' [orang campuran] (Retsikas, 2007a). This identification is largely the outcome of spatial patterns of intermingled living and a series of transactions carried out over several successive generations that involve transfers of food, children as spouses, ancestors and prayers. In marked contrast to West Kalimantan, where the presence of Madurese migrants is historically tied to conflict with Dayak and Malay groups (Peluso and Harwell, 2001), in Probolinggo, and East Java more generally, Islam as a religion in common for Javanese and Madurese migrants and the absence of competition for scarce resources phrased in ethnic terms, have provided the basis for the displacement of ethnic boundaries and have facilitated processes of mixing. ${ }^{3}$

The inhabitants of these three kampong range from relatively wealthy to poor. The former are mostly landowners of several hectares of irrigated rice fields, some of whom are also engaged in trading goods with the national and provincial capitals. Some of the wealthy ones also happen to be members of the state bureaucracy and of the religious elite, the famous kyai. As for the poorer households, these are pursuing livelihoods both in the formal and informal economy as agricultural workers, petty traders of a bewildering variety of goods, and factory workers in multinational industries located further afield. Shop owners, along with professionals such as teachers and nurses, occupy the middle level of affluence. As in other parts of rural and peri-urban Java, a sense of relative equality, however, informs the conceptualization of social relations, as people are eager to highlight the absence of extreme polarities of wealth and to emphasize processes of interaction and cooperation.

3 The data this article is based on are drawn mainly from conversations I had with Madurophone informants, and many of the key terms are in Madurese, as spoken in Probolinggo. However, I have not noticed any differences in the ways that Javanophone and Madurophone locals speak of sorcery and sorcerers. It may be worth noting that across Java, ethnic Javanese stereotypically associate Madurese with physical violence, while at the same time ethnic Madurese accuse Javanese of being more prone to and adept in employing the mystical arts in exacting revenge. The distinction between physical and mystical violence is itself part of the pervasive halus-kasar distinction I have discussed elsewhere with special reference to regional ethnic distinctions (Retsikas, 2007a). 
In this community, violence, or the threat of it, is by no means absent. As I have noted elsewhere, violence in the form of sorcery is a pervasive presence intrinsically associated with uncertainty over the intentions and 'true' feelings of social others (Retsikas, 2006). As Wikan observes with respect to neighbouring Bali, 'behind a surface of aestheticism, grace, and gaiety, we found social uneasiness, great concern with the individual thoughts and intentions of others, and ubiquitous fear. A coat of politesse, and of forced, almost obsessive conviviality lends to Balinese life an aura of poise [. . . but] this façade of good feelings fosters fear in turn.' (1987, p 338) Given this fear's ubiquity, the relative scarcity of ethnographic documentation on sorcery in Java and Bali may at first appear surprising. Roy Ellen (1993), noting the highly influential Africanist and Melanesianist literatures on sorcery and witchcraft, observes that in South East Asia, similar studies have been few and far between. This absence he attributes to the fact that in this region such phenomena do not translate themselves into social problems as they do in Africa, for example, with the periodic rise of anti-witchcraft movements and public witch trials. ${ }^{4}$ However, there is another reason that explains this scarcity. In Java, sorcery evokes shame and silence. It is not something people casually bring into conversations. Quite the contrary; the less it is spoken about, the better. This quality of invisibility is, moreover, intrinsic to sorcery, the rituals of which are both secretive and private, and its mode of violence is supernatural. However, as the following case demonstrates, its existence is doubted by none.

Three days after Ibu Surina's funeral, her nephew, a young unmarried man named Putro, confided in me that the family, saddened by her unexpected death, felt that something untoward was involved. Ibu Surina was a 55-year-old widow with two married sons and three grandchildren, who had never suffered from any major illnesses, being

4 There are of course exemptions such as the witchcraft panics and the ninja assassinations that Siegel (2006) and I (2006) have discussed with respect to late 1990 s Java. Both these works place emphasis on the history that informs sorcery accusations and sorcery-associated violence. Siegel points out that the widespread fear of sorcerers was directly related to the collapse of the structures of recognition that the end of the New Order brought about, while I have emphasized the continuities that popular imagination established between the ninja attacks on alleged sorcerers and the communist purges of 1965-66. In the present paper, however, I have decided for reasons of space to bracket concerns over history and national politics in favour of a novel path of analysis, showing, I hope, the parallel operation of an altogether different logic. 
economically active and 'strong as a man'. Her falling sick and dying occurred within the space of four days. As in most cases of abrupt and tortuous passing, everyone's mind focuses on sorcery. Putro explained that his aunt had been involved in a dispute with a neighbour about a small garden plot that stood between their respective houses. Ibu Surina had been cultivating the plot with vegetables to sell in the market for the past seven years - that is, since the owner of the plot had left for Surabaya to take up a post in the civil service there. The owner was a relatively well-off teacher, Hajja Mariam. The two women were said to have been close to each other since childhood. It was out of 'sisterly love' and piety, Putro explained, that Hajja Mariam offered the plot to Ibu Surina to cultivate so as to augment her income, which had become desperately meagre since the death of her husband. This generous gesture, however, had displeased Hajja Mariam's first cousin who was also Ibu Surina's next-door neighbour. Ibu Halima, the cousin in question, had been involved in an altercation with Ibu Surina a couple of months before the latter's death. The reason for this had to do with Ibu Halima erecting a makeshift fence around the garden during Ibu Surina's short-term absence, with a public confrontation following Ibu Surina's demands for an explanation. According to Putro, Ibu Halima had been trying to convince Hajja Mariam to sell the garden to her. She wanted to build a house there for one of her daughters who was about to get married. Hajja Mariam, however, had repeatedly declined to sell, stressing the dire consequences Ibu Surina would have to face due to being deprived of her main income. 'Now,' Putro whispered, 'she can have it; she can build the house ... my aunt is gone'.

I could provide several more cases. The general point is that in Java, sorcery accusations always tend to focus on one's intimates, for sorcery is held to be practised against relatives, neighbours, friends and work colleagues (Geertz, 1960, p 110; Wessing, 1996). It is among people of these categories that elaborate forms of etiquette and deference are largely absent, normally reserved for one's superiors and distant acquaintances and/or strangers. Relationships with one's equals and associates are marked by sociable mutuality in everyday situations, exemplified in relaxed conversing, informal visiting, playing, teasing, good humour and affective comfort, as well as by economic cooperation and ritual exchanges. The fact that sorcery is the flip side of the way that convivial intimacy is experienced in Java highlights the precarious and ambivalent nature of sociality and the fragility of the trust involved. Situated on the same 'plateau of intensity' (Deleuze and Guattari, 1987, 
p 22), conviviality harbours aggression, and predation emerges out of the inherent risks and hazards of engagement with others. Unrequited love, rejection of a marriage proposal, adultery, betrayal of a friendship, failure of reciprocation, deterioration of an economic partnership, frustrations relating to inheritance imbalances are all phrased in terms of an offence delivered and an ensuing loss of face. Alleged resorting to sorcery empowers the offended party, which, by taking command of the fortunes of those who failed to behave according to expectations, allows for the exacting of revenge and the regaining of face.

Writing with respect to Sinhalese Buddhists, Kapferer (1997) notes that sorcery is a creative phenomenon, playing a constitutive role in that it furnishes people with the means through which they can make and remake their lives. As such, sorcery has more than a merely expressive function. It is neither simply about the articulation of latent conflicts and contradictions in local political relations (Gluckman, 1956) and the release of tensions (Turner, 1957) nor solely about the vocalization of resistance to neo-liberalism, globalization and the alienation of labour under colonial and post-colonial regimes (Comaroff and Comaroff, 1993). Kapferer argues that more generally, sorcery is about the 'contingency and magicality of human existence', about 'intentionality' and 'consciousness', 'highlighting the truly extraordinary capacity of humans to create and destroy the circumstances' in which they find themselves. To the extent that sorcery is about agency, I would add that it is also about affectivity, the capacity for being sensitive and responsive mentally, bodily and emotionally to social relations. As I go on to show later, vulnerability and susceptibility to sorcery stem largely from this condition of openness and receptivity.

The definition of sorcery as agency and affect is encapsulated in local conceptions of it as both a murder and an illness. As penyaket alos (Madurese), a refined or invisible illness, it is attributed to the intervention of a supernatural agent, most commonly an evil spirit, which acts under the orders of a sorcerer. Diagnosis is subsequent to the inefficacy of herbal and biomedical treatments to remedy a series of symptoms (Jordaan, 1985). As a rajha pate alos (Madurese), a spiritinduced murder, sorcery is the invisible anger and rage of the offended party who, in his or her attempt to seek retribution, employs the services of a sorcerer. To construe sorcery as spirit-induced murder is to say that its violence is qualitatively different from a slap in the face or an order shouted out loud - acts in which the identity of the agent is public. In sorcery, both the instigator and the sorcerer remain hidden, despite 
rumours and whispered accusations. Here, illness is a response to anger, while affect is the outcome of and a precondition for agency. In what follows, I discuss their gendered characteristics.

\section{Masculine and feminine bodies}

It was Sunday afternoon, and Mas Bukhari and I were having a talk about his search for a wife. Mas Bukhari was an alumnus of the Islamic boarding school I was staying at, and over time we had come to form a close friendship; we were of a similar age, both bachelors, and both in search of knowledge. Mas Bukhari, the son of a farmer who had died when he was still a boy, had been the disciple of three Islamic scholars, all of whom had entrusted him not only with the basics of the faith, but also with the necessary knowledge [ilmu] for facing misfortunes - his own and others'. As an apprentice healer himself, he liked talking in riddles and posing paradoxes, often laughing in the face of apparent contradictions. "Having sex with a wife culminates in a "little" death [kematian sementara, temporary death]', he said, looking at me with a straight face. Somewhat taken aback, I replied that it was Freud who had equated death with orgasm, but Mas Bukhari insisted that these were the words of one of his teachers, preparing him for such an eventuality. 'The thing is,' he continued, directing attention to the real point he was trying to make before I had interrupted him, 'how is it possible for the one who bears sharp weapons [senjata tajam, a common euphemism for the penis] to be killed, while the unarmed one remains invulnerable [kebal] and asking for more?' While the workings of female sexuality seem to have been somewhat missed in this formulation, Mas Bukhari's observation nonetheless revealed one of the central paradoxes that, at least from a male point of view, surrounds femininity: namely, its inherent vulnerability due to being the penetrated rather than penetrating, being coupled with a potency that defies (little) death. At the same time, this formulation portrays masculinity as in danger of being overcome by both affective death and by an insatiable femininity, a susceptibility normally suppressed in common designations of masculinity as being harder, more closed and able to endure extreme conditions.

Mas Bukhari's statement is part of a long tradition of what Florida terms as a 'treatment of sexuality which may be found in the Javanese classics' and which uses a 'conventional martial imagery [. . .] to depict sexual relations between men and women' (1996, p 209). This imagery 
was reiterated to me on countless occasions during fieldwork. Women, for example, would ask me teasingly whether I had a 'sweet enemy' [moso manes, Madurese], meaning a wife or a fiancée; herbal remedies for male fertility problems were referred to as dedicated to 'filling up the stock of bullets' [mengisi peluru]; and the penis was euphemistically likened to a kris, a dragon-shaped dagger. ${ }^{5}$ In the wars of intimacy in which lovers in Java engage, men commonly occupy the role of the aggressor, with female genitalia being portrayed as a wound, the outcome of the insertion of daggers, and a sign of the softness of female bodies and their innate vulnerability. These themes are confirmed by Niehof, who observes that on the island of Madura, where several of the ancestors of Alas Niser hailed from, the bride 'after her defloration, is supposed to faint', performing a death of sorts (1992, p 175). Her unconscious body is then washed, has prayers recited over it, and is dressed in a new set of clothes, all acts that evoke the handling of corpses. However, parallel to the privileging of masculinity as endowed with a deadly erotic agency, in other contexts and situations the powers of femininity both for destruction and the generation of life are acknowledged and celebrated. In this regard, Mas Bukhari's paradox was the result of the collapsing of the distinctiveness of contexts that, in turn, elicited laughter as well as terror.

In Java, as in other parts of the world, knowledge about persons and social status are enshrined in cultural perceptions and experiences of the body. Gender, age, class and ethnicity manifest themselves in hierarchies between bodies (male over female, mature over immature, high over low, us over them) and within bodies (head and feet, the inner and the outer) (Osella and Osella, 1999). Such hierarchies are, however, neither absolute nor complete. In their path-breaking treatment of gender conceptualizations in island South East Asia, both Peletz (1996) and Brenner (1998) argue that 'hegemonic' or 'official representations' of gender, according to which men are relatively superior because they are more successful in regulating their desires, coexist with 'counter-hegemonic' or 'practical representations', which invert the terms of the equation. What is even more important is that the contestable nature of the hierarchies involved is underwritten by both women and men, alternating in their evaluations of gender superiority according to context and the aims at hand. To make this picture of

5 This is not so much a case of 'we marry our enemies' as 'our enemies are those we marry'. 
gender relations even more complicated, it is also necessary to add here that such hierarchies are embedded within a discourse that emphasizes the complementarity of men and women as husbands and wives, and brothers and sisters, highlighting the need for cooperation for the wellbeing of the household (Errington, 1990; Ong, 1989).

The question of the degree of control over the body's openness and closed-ness is of central importance in the articulation of sex wars and the conceptualization of hierarchies. In particular, the themes of achieving and/or being endowed with a high degree of bodily integrity, closure and impermeability inform Javanese understandings of power that Anderson's (1972) work discusses most eloquently. The interaction of the body-person with social others is deemed to be inherently dangerous and in need of careful regulation. The body orifices mark these sensitive areas where exteriorizations and interiorizations take place, actions that can affect and alter one's identity (Retsikas, 2007a). Potency [kesaktian] and high status are inherent in the mastery of such flows and interactions, in the sense that through disciplined observance of social norms and the performance of ascetic exercises (fasting, prayer and meditation, often carried out in isolation), one achieves and/or enhances one's control over the outings and the comings into the body. Mastery over one's own bodily integrity extends outwards, and is equated with mastery over other people and the natural environment (Anderson, 1972, p 13).

All my informants, men and women, of high status and low, agreed that female bodies were more open and permeable than male ones, and that feminine persons were less capable of achieving control over their bodies. The concept of nafsu [nafs in Arabic], and especially ideas and practices regarding menstruation, were key to marking this difference. Nafsu is commonly translated as 'natural appetite', 'instinct', 'lust' and 'desire', primarily for food, sex and material possessions. It carries strong derogatory connotations, even though the satisfaction of such needs is acknowledged as integral in maintaining well-being. Attributes that are singled out for moral criticism include complacency, absence of restraint and excessive indulgence, attributes that are strongly feminized. In this regard, my informants would often narrate the deceitful character of Hawah [Eve], the wife of Adam. 'Nabi Adam was created from clay,' a young female pupil informed me. 'Hawah was created from Adam's rib,' she continued, 'and the rib is the most crooked [paling cacat] part of the body. If you try to make it straight, it will break; even broken, it still is crooked.' The fragility and non-straightforwardness of the 'rib' 
is reinforced by Hawah's role in the Fall of mankind: that is, the ease with which she was deceived by Satan, and the lead she took in persuading Adam to eat the forbidden fruit. Their subsequent exit from Paradise is commonly held by Muslims in Java to have ushered in both the possibility of procreation and the menses. The same female informant explained the origins of menstruation in terms of a sacred physiology as punishment for Hawah's role in corrupting Adam. 'Hawah was condemned to bleed for that once a month by Allah. Since then, we all bleed', she added.

Menstruating bodies are female bodies. Male bodies do not menstruate, having one less orifice, one less breach. Bodies that menstruate manifest an innate lack of control over bodily functions and integrity (see also Hoskins, 2002). Both this lack of agency and the dangers that the transgression of bodily boundaries poses are connoted in the Quran by the term adha - Surah 2, p 222 - which is variously translated as 'filth', 'hurt', 'pollution' and 'vulnerable condition'. In addition to the menses, both female and male involuntary sexual emissions during sleep are referred to as adha, as is the voluntary exchange of fluids during sexual intercourse. All these cases call for the performance of ghusl, a short cleansing ritual. In the case of the menses though, a stricter regime of seclusion and enclosure is required. Menstruating women in Java, as in other Islamic societies, are thought of as particularly susceptible to evil spirit attacks, which are attracted to the smell of blood. Their movements are carefully regulated as much by this fear as by the fact that they can not enter spaces reserved for the performance of solat. ${ }^{6}$ Restrictions regarding spousal intimacy include the prohibition of sex while the menses last, and communication with the sacred is equally impeded by the proscription against touching the Quran, performing solat, fasting and circumambulation of the Kaaba during the hajj. Contrary to common sense, these restrictions do not provide the basis of female oppression. Rather, in effecting seclusion, they act as defences against the vulnerability of an open and permeable body and as externally lent supports in aid of recovering agency.

Douglas explains the defilement of menstrual blood as a result of it being 'a person manqué' (1966, p 96), a sign of infertility, or at least, the failure to conceive, equivalent to an aborted foetus, and thus associated with death. Male informants made similar associations, arguing that breaking the taboo against having sex with a menstruating

6 Solat are ritual prayers, which are obligatory and performed five times daily. 
woman results in the festering/putrefaction [busso, Madurese] of the penis, and thus in male impotence, which could become permanent if the taboo were to be broken with regularity. The death by contagion connoted here is, however, different from death in the erotic battlefield of socially and religiously sanctioned sexual encounters to which Mas Bukhari's comments alluded. To understand the latter more fully, we need to see both menstruation and femininity as ambivalent conditions. On the one hand, menstruation and femininity index nafsu as rapaciousness and insatiability, conditions pertaining to all humans irrespective of their gender; on the other hand, they connote openness, receptivity and affective capacities for the generation of life in the sense that bearing a child implies, which indeed requires menstruation. Childbearing itself rests on forms of agency that male bodies lack; the production of new life is a female capacity. Mas Bukhari, when prompted, likened erotic death to 'having one's hot kris cooled down [menjadi tenang kembali] by the vagina' and other male informants associated women with sawah [irrigated rice fields], saying that the man provides the seed and the woman the soil. This was not a metaphor, as in matrifocal Alas Niser, both houses and sawah are usually inherited by daughters. One particular man linked the origin of bull races to the practice of parading bulls over rice fields during the dry season so as to trigger earth fertility. This could not, however, be completed until the rains came and the fields were saturated with water, he added. In Java, coolness is a positive value as it is associated with the sensations of inner calmness and outward tranquillity that control over the nafsu generates. Moreover, it is associated closely with water, which in turn indexes purity. For my informants, both men and women, the purity of femininity stems from the capacity for bearing children.

As Djajadiningrat-Nieuwenhuis observes, from the late nineteenth century onwards, a combination of Dutch bourgeois values and 'traditional' Javanese ones, further promoted by the New Order state, led to the formation of the cult of $i b u$ - the mother. Ibu-ism, which Islam also supports and promotes, 'sanctions any action [undertaken by a woman] provided it is taken as a mother who is looking after her family, a group, a class, a company or the state' (1992, p 44). The image is of a woman who acts for the benefit of a collectivity, willing to sacrifice her body, labour and time for the benefit of those intimate others of which she is a part, most notably her children. Femininity as motherhood is conceived of as active. It is thought that the transformation of semen and uterine blood in the womb into a foetus, and its growth 
there, manifest unique forms of agency, which find their post-natal equivalent in the transformation of money that women almost singlehandedly transform into food, clothes, household possessions, property, etc (Carsten, 1997). Such agentive capacities are also manifested in what Sullivan (1994) describes as réwang [to help, Javanese] networks: that is, networks of reciprocal labour exchanges, which connect disparate households, mediating otherness and establishing community. In Alas Niser, such activities are said to stem from sepat niser (Madurese), the charitable and merciful 'nature' of femininity.

\section{Androgyny}

The metonymic relations pertaining amongst women, blood and affective openness on the one hand, and men, semen and disciplined closed-ness on the other, bespeak closely associated forms of being and acting, rather than diametrically opposed ones. Both agency and affectivity are present in male and female forms, albeit with distinct emphases and implications. Female persons achieve agency in motherhood through being receptive and responsive to masculine activity, while male persons are acted upon in sexual encounters through being 'swallowed' by their wives and made to emit semen, rather than blood, becoming thus, in turn, open and vulnerable, and dirty. The two forms of being exist as transformations of each other, with masculinity inhering in femininity, and femininity subsisting in masculinity, a mode of relationship that Deleuze and Guattari (1987) refer to as 'reciprocal presupposition'. ${ }^{7}$ Following this relationship, it is only in intensive encounters that people's capacities become gendered as they temporarily assume more definite positions. We have already seen the martial and marital tensions and antagonisms involved in sexual encounters. Being singularly male or singularly female is achieved in social relations and specific contexts such as those of marriage and sex by the gendering of qualities. Such qualities, namely agency and affect,

7 Reciprocal presupposition is a relationship characterized by multiplicity, intensity and mutual implication. As such, it differs in significant ways from complementarity as commonly understood in the literature on gender in South East Asia. Reciprocal presupposition substitutes the dialectical connotations of a harmonious combination of entities endowed with predetermined and stable identities with an emphasis on unstable becomings (see conclusion). Such becomings are themselves predicated on movement and disjunctive synthesis rather than on conciliation and stasis, and they refer to subjects that contain within themselves heterogeneous elements: in our case, both feminine and masculine characteristics. 
are, nevertheless, shared by both genders. It is their relational manifestation that differs. This difference is, in turn, the result of acts of eclipsing or displacing the similarity that underwrites gendered personhood.

This foundational similarity is captured by Strathern's (1988) concept of androgyny - meaning that persons carry within them both male and female parts, with their singular gender identity emerging contextually and situationally through the privileging of one at the expense of the other. In my fieldwork locality, androgyny is partly grounded on ideas of conception, the transfiguration of substances and ideas and practices of siblingship. The elicitation of singularity out of composite androgyny is carried out in a multitude of contexts. Here, I concentrate only on circumcision and sorcery. Institutionalized genderswitching, as in certain dance performances and practices of transvestism such as those of waria [male transvestites] and warok performers (see Oetomo, 1996; Boellstorff, 2004; Wilson, 2007), reminds us of the limits of this elicitation in taking full effect, with the excess that androgyny instantiates coming to full force. ${ }^{8}$

In Alas Niser, children are considered to be made up of the combined role played by both genders in the production of human beings (see also Beatty, 1999, p 167). The body of the foetus is held to be composed of a mixture in which the 'man's liquid' (sperm) can no longer be differentiated from 'female liquid' (uterine blood). However, the difference between semen and blood is in other contexts negated. Some male informants argue that semen is 'a kind of blood' that comes out white because it passes through the kidneys. Other (again male) informants claim that semen is actually bone marrow, with the penis being an extension of the spine. For the latter, bone marrow is a kind of thicker, cooler white or yellowish blood. Similarly, traditional midwives in Alas Niser construe breast milk as blood, and endow a specific herbal medicine [jamo pejjeen, Madurese], which new mothers consume, with the capacity to turn the blood located in their breasts into white baby

8 In the Indicized cultures of pre-modern island South East Asia, androgyny, variously framed in institutionalized transvestism, gender-switching and homosexuality, 'represent[ed] the desirability of producing perfect unity, forming an undifferentiated unitary whole' by re-attaching together what has been separated (Errington, 1990, p 52). Some androgynous beings such as the bissu of southern Sulawesi were held to enjoy a close relationship with the sacred and to embody cosmic balance. Members of a contemporary Hinduism-inspired Javanese sect studied by Beatty (1999, p 190) in East Java similarly construe their founder as an androgynous person who, in addition, was of indeterminate origins and age. 
food. Here, the gendered opposition of semen and uterine blood is cancelled out, for it is made to appear as founded on the transfiguration of a single, genderless, androgynous life substance.

Being internally gender-composite, social persons are also externally so. This is so because, in distinct South East Asian fashion, they are conceptualized as parts of a sibling set (Retsikas, 2007b). The quintessential sibling set is that of brother and sister, or alternatively, husband and wife, who address each other as 'older brother/younger sister' until their first offspring is born. Together they perform the ritual and social duties of house production and reproduction, thus constituting at a higher level a single, yet divisible unity. As Howell observes for the Lio of Flores in eastern Indonesia, 'in those contexts where they act as a crosssex sibling couple, [persons] can be interpreted as androgynous beings' (1995, p 258) in the sense that they correspond to only one member of a pair. According to some versions, Alas Niser was founded by a set of siblings who arrived from Madura in the early nineteenth century, cleared the forest and established the first human community. The androgynous origin of the community is replicated in key community events such as the famous ritual rice meals. In Alas Niser, rice meals dedicated to the promotion of life, such as slametan surrounding pregnancy and childbirth, are commonly female affairs, with women acting as representatives of their respective households, while funeral rice meals [tahlilan] are predominantly male ones. For an array of other slametan such as those held for marriage and circumcision ceremonies, men and women are both present - though engaged in distinct tasks, with men most commonly leading the prayer sessions and speech making, and women preoccupied with cooking and serving meals. The disjunctive synthesis that houses encode is also manifested in spatial arrangements, with male spaces constantly implicating and presupposing female ones. Small prayer houses located within residential compounds are predominantly male spaces where men perform their afternoon and evening prayers and engage in relaxed conversations about day-to-day life, often sleeping there too. Such men are related to each other through their wives who are siblings of various degrees, for the house compounds are inherited by women, and are thus marked as female spaces. Furthermore, in rice agriculture, ploughing is performed by men only, while the planting of rice seedlings is carried out by women. The latter are also in charge of harvesting, with transportation being done mainly by men.

Perhaps the most telling instance of androgyny is to be found in male 




Figure 1. The gender uniform 'newly-weds'.

circumcision festivities. When several 'male' children are to be circumcised together, a hopping horse [jaran kenca, Madurese] performance is held during the day if their parents are willing to go to great financial expense. These 'male' children along with 'female' ones, with the latter being the sisters, cousins or neighbours of the former, are all made up and dressed in similar, indistinguishable fashion that makes it extremely hard to tell 'male' and 'female' apart (see Figure 1). All the children are then paraded around the locality on extravagantly decorated horses, which stop in front of houses and hop to the tune of the music (see Figure 2). The children are referred to collectively as kemanten, or newly-weds, with the word being gender-neutral in the sense that it connotes as much the bridegroom as the bride.

The choice of circumcision for the parading of androgyny is no mere coincidence, for circumcision evinces both masculine and feminine bodies. As Boddy observes, 'circumcision accomplishes the social definition of a child's sex [sic] by removing physical characteristics deemed appropriate to his or her opposite' (1982, p 688). In the case of boys in Alas Niser, this relates to the prepuce of the penis, which covers the hasyafah [glans penis] and in the case of girls, to the soft scratching 


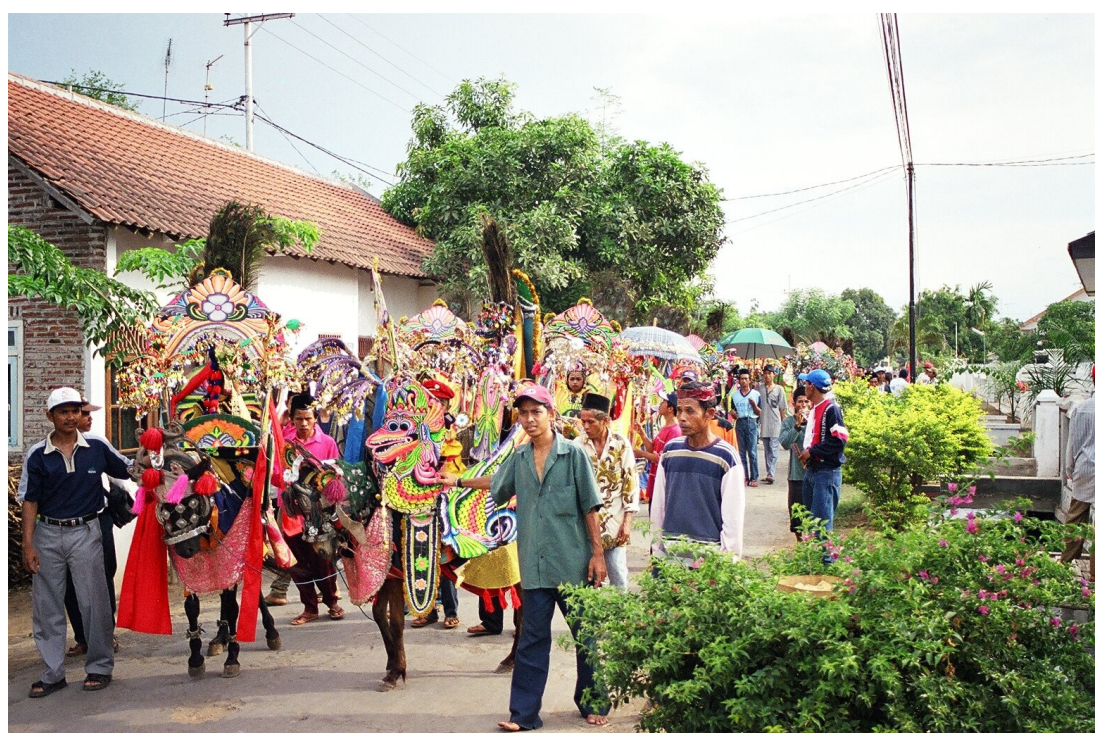

Figure 2. Parading androgyny.

rather than the actual removal of the prepuce of the clitoris [jelik, Madurese] with or without bleeding (see also Ida, 2005). The purpose of scratching the clitoris, an act performed without much ceremony and when the girls are still 7-40 days old, is said to be to make them start menstruation later, rendering them fertile and capable of marriage. The presence of girls in the hopping horse performance anticipates these events and calls for the literal uncovering of masculinity. This was best put by a 15-year-old girl who, inquiring about whether I was circumcised or not, noted that 'the banana tastes better when peeled' [makan pisang lebih enak jika dibuka kulitnya].

\section{'Chronicle of a death foretold'}

Circumcision is carried out most usually by dukun, while nurses and physicians do occasionally feature too, especially among educated, upper class people. In general, dukun are persons with sacred abilities to heal, and such persons are usually suspected of having additional powers to harm, particularly of dabbling in sorcery (Retsikas, 2006). With regard to circumcision, dukun have the capacity to induce gender singularity 
through the 'removal' of androgynous features. In the case of sorcery, I suggest that $d u k u n$ apply their secret know-how so as to transform the always-present androgyny into masculinity first and then, into femininity. The mystical rendering of the victim's body as open and vulnerable is central to the dukun's capacity to inflict pain and death on others. This series of gender transformations is the intended effect of secretive sorcery rituals, which employ a variety of objects and techniques so as to create relations of affinity and enforce marriage upon the victim. In this context, death is the outcome of involuntary sex with non-human beings.

Given the general reluctance of people in Java to talk openly and publicly about sorcery, and the fact that people who are suspected of being sorcerers are normally ostracized and occasionally killed by their neighbours, it is no surprise that during my 18 months of fieldwork, I never heard anyone admitting to being a sorcerer. Similarly, I have never met anyone who endorsed hiring one as a moral course of action for avenging insults. In addition, given the secrecy of the act, I have never witnessed the casting of a sorcery spell. What I present here is information I gathered quite late in my fieldwork through talking to dukun who perform healing and counter-sorcery rituals. These were dukun whose moral credentials were the least contested, given their observance of Islamic stipulations in their everyday lives and their generosity to kin and neighbours. Their descriptions of what may be involved in sorcery sessions were obtained after having spent a considerable amount of time in their houses, observing them treat sick people, often accompanied by Mas Bukhari, who was instrumental in introducing me to them and discussing with me at great length the often enigmatic and piecemeal information offered. The piecemeal descriptions, allusions and hints I am working with here refer to imagined activities rather than actual rites performed by sorcerers. Yet to qualify them as imagined does not make them any less real, concrete or significant for our understanding of the conceptual universe and behavioural patterns of the peoples of East Java.

In Alas Niser, as in Malaysia (Peletz, 1993) and south India (Nabokov, 2000), it is widely assumed that the performance of sorcery involves four parties: the sorcerer; the knowledge/power/evil spirit [ilmu] he commands; the sorcerer's client: that is, the person who has ordered the casting of the spell; and the victim. What is quite particular in the Javanese case is that, during the course of the sorcery rite, the relations pertaining amongst these four actors are defined and redefined in an 
exact manner. The sorcerer and the client are made to stand as bhesan (Madurese) to each other (see below), a reciprocal term of address used by parents whose children are married to each other. Moreover, the gender of this first pair of actors is defined as masculine throughout the rite. This is in agreement with the gender of persons who are eligible to act as wali [guardian, legal representative] in Islamic marriage law. At the same time, the gender of the victim and the ilmu - that is, our marriage candidates, is transformed in the course of the rite, with these two occupying alternate gender positions. In contrast to Thailand, where sorcery rites draw extensively upon funerals (Rajah, 2005), in East Java they evoke and invert weddings.

The sorcerer [dukun sihir, dukun santet, Indonesian, or dhukon kemudhung, Madurese] is said to achieve a self capable of deliberately destroying others through becoming hyper-masculine. In the first instance, dukun suspected of being sorcerers are usually of the male sex, although female dukun are not excluded by definition from such suspicions. These people are reputed to have acquired the necessary knowledge/power [ilmu] through apprenticeship. The apprenticeship involves the undertaking of ascetic exercises [tirakat] such as fasting, long periods of isolation in a forest or a sacred place such as the tomb of a potent person, accompanied by repeated recitations of magic formulas written in Arabic, Javanese or Madurese, under the guidance of a senior sorcerer. Tirakat are commonly undertaken by all aspiring dukun and those in search of benevolent knowledge such as Sufi and Javanist [kejawen] mystics as the primary means of achieving control over nafsu (Keeler, 1987; Beatty, 1999). At the same time, tirakat is also undertaken by non-specialists who want to affect the outcome of a course of action such as school exams, promotion rounds, business ventures, etc. In the case of sorcery, tirakat is held to be integral in bringing the apprentice into contact with especially malevolent, or at least morally ambiguous, spirits. I was told that tirakat by aspiring sorcerers is usually performed in cemeteries on Thursday nights or during the first night of the Javanese month of Sura - times when the frustrated spirits of murdered people are extremely active. Alternatively, tirakat may attract a setan or a non-Muslim jinn, entities that are the sworn enemies of humankind in its struggle to obey Allah's commandments. Such encounters are extremely dangerous as the spirits assume the forms of fearful animals such as tigers and serpents, ready to prey on the apprentice. Running away out of fear results in the apprentice going mad. The motif of disempowerment and loss of the natural ability to 
command oneself stressed here is also highlighted in attributing failure in tirakat, with the apprentice being seduced by a spirit that has taken the form of a beautiful woman. To abandon tirakat due to giving in to the erotic nafsu is held as analogous to being overtaken by fear: both result in the apprentice becoming the spirit's slave [khadam]. In contrast, successful completion of the trials ends with the spirit becoming the apprentice's slave and willing to perform whatever tasks are assigned to it by its master. However, this power relationship is said to be inverted after the sorcerer's death, whereupon he will find himself as the spirit's servant in the domain of Hell in the afterlife.

The hyper-masculinity of sorcerers, whatever their actual sex, is manifested in them seeking continually to increase their levels of selfcontrol, to seek detachment from other human beings through pursuing isolation and discipline routines, to withstand madness and avert possible possession in their dealings with non-human agents, building hard and impenetrable bodies that can withstand the challenges they are presented with by malevolent spirits. However, I should stress at this point that the hyper-masculinity of sorcerers is a relational and thus unfixed attribute that is sought after and solidified only in relation to both other human beings and malevolent supernatural agents. As tirakat is generally employed in the larger context of Javanese spiritual practices that aim to bring humans into contact with a diverse array of spirits, angels and Allah Himself, the gender of the person undertaking such practices can equally be constituted from another perspective and with regard to another set of relations as female. Both Sufi and kejawen discourses place emphasis on the knowledge-seeker becoming the receptacle of other-worldly power (Anderson, 1972; Woodward, 1989) and I have repeatedly heard healers and Sufi mystics in Probolinggo construing their acquisition of special capacities to be the result of their voluntary penetration by benevolent spirits, and in one case at least by the divine itself (Retsikas, 2008). The fundamental indeterminacy of the gender of $i l m u$ seekers lends further support to my overall argument regarding the essential androgyny of persons. In this respect, the gender of ilmu seekers alternates according to the kinds of agents with which they interact, the latter's place in the overall hierarchy that informs cosmological understandings, and the mode of interaction: that is, voluntary penetration, involuntary possession, contractual bondage, etc. Their gender also shifts contextually according to whether it is relations with supernatural agents or with other human beings that are the primary concern. 
As far as sorcerers and their relations with humans are concerned, their hyper-masculinity is manifested in them being construed as full of agency and devoid of affectivity, for dukun santet do not hesitate to sacrifice a close relative or neighbour to the insatiable demands of the evil spirit for victims. The ilmu is commonly construed as making periodic demands upon the dukun, with the continuity of its services depending upon the latter meeting them. If there is a shortage of victims due to the absence of clients, the evil spirit might turn against its master and 'eat' him. In these circumstances, the dukun has to offer a substitute so as to save himself. Such a substitute is thought to come from the dukun's own family or his neighbours.

If the sorcerer is hyper-masculine, what about the gender of the other actors in the sorcery drama? The gendering of the evil spirit as female is accomplished both by its intimate association with the insatiability of nafsu and the deadly desire for victims, as well as by its portrayal as an ambivalent slave - an ambivalence that draws upon that surrounding menstruation. Furthermore, the elicitation of the spirit's femininity is accomplished through the denotation of the fee the client has to pay the sorcerer as mahar. Mahar (mahr in Arabic; also referred to as mas kawin) is an essential part of the marriage contract [akad nikah] according to both the Sharia' $h$ and its interpretation in the Indonesian Marriage Law of 1984. Mahar is usually construed as a bridal gift rather than as purchase money, and is the property of the bride (Spies, 2007). In Alas Niser, it is most often presented during the akad nikah ceremony by the groom's wali (or the groom) to the wali of the bride, an act witnessed by an all-male congregation. Sometimes it is also presented by the groom directly to the bride in their first meeting after the akad nikah has been completed. In all Islamic societies, the payment of mahar is of central importance for the legality of the union. ${ }^{9}$

The designation of the fee as mahar alludes not only to sorcery as a kind of marriage (albeit an inverted one, since it is aimed not at the regeneration of life, but at its destruction), but its payment also defines the two parties - the sorcerer and his client - as wali and thus, male and bhesan: that is, persons related through the marriage of their children.

9 During my fieldwork, the mahar consisted of a small amount of money (say, 100,000 rupiah) or a Quran, a prayer dress, a ritual string and a prayer rug. Geertz notes that in the 1950s, it amounted to five rupiah (1960, p 56). Koentjaraningrat, who construes it as 'a small symbolic bride price', writes that in Central Java it consists of 'silver to the value of five Dutch florins [!] and a Qur'ān' (1989, p 127). 
The client as well as the sorcerer might well be of the female sex, but from the perspective of the exchanges they are engaged in, they stand as wali to each other, and thus as males: the exchange of the gifts engenders them in masculine form. In addition, the payment of mahar has definite consequences for the gender of the victim and the malevolent spirit. The evil ilmu is configured as female; it stands as the sorcerer's daughter, for the sorcerer receives the mahar in his capacity as the daughter's wali. In turn, the potential victim, who may be either male or female, is from this same perspective elicited as male, occupying the last possible position in this set of relationships: he is the bridegroom. What follows has largely to do with the emasculation of the bridegroom and his turning into the bride.

Sorcery is said to be performed only at nights in a windowless room, with the sorcerer summoning the spirit through incense burning and the presentation of offerings. Informants gave diverse descriptions of offerings, but all insisted that these were determined by the spirit and might include clothes, sweets and perfumes. They were all adamant that flowers - roses, jasmine and cananga - had to be spread in the middle of the room. These flowers are also used in different stages of the marriage ceremony to purify the bride and they adorn the newlyweds' bedroom. Their choice is intimately related to their colours (red, white and green respectively), which index the three elements comprising human beings: namely the mother's uterine blood, the father's sperm, and roh, the animating principle that comes from Allah. According to some informants, the summoning of the spirit also demands that the sorcerer should urinate on the Quran or copulate on it with his wife.

The most potent forms of sorcery - that is, those aimed at inflicting death - involve the use of effigies as the embodiment of the groomvictim (see also Koentjaraningrat, 1989, p 419; Wessing, 1996, p 27). While my informants confessed ignorance as to the materials used for the shaping of these effigies, they all agreed on the importance of using soil taken from the grave of an embryo with which to rub the effigy. In Alas Niser, embryos older than four months are accorded quasifunerals, being wrapped in the same white cotton shroud used for full persons. However, their burial is unmarked by the usual ceremonies surrounding death. Dead embryos are considered extremely potent and they are sometimes buried at the very centre of blighted rice fields or close to the water gate, with the expectation that they will aid the plants' recovery. It is possible that the rubbing of the effigy with soil taken 
from the dead embryo's grave serves to animate it, activating it with its latent life force.

The presencing of the bridegroom-victim is also achieved by means of the inclusion of objects and substances that are in sympathetic relation to him. The client has to supply the sorcerer with parts of the intended victim's clothes, or soil on which he has stepped barefoot that is, objects that contain his sweat. Of the highest value are the victim's fingernails and hair, substances that once belonged to his body and thus partake of his identity. A photograph may also be used, especially when the aim of the ritual is to make the victim fall in love with the client.

According to my informants, these personal objects are wrapped together in a bundle that contains other sharp and rusty objects such as needles, nails, parts of broken mirrors and iron chains, the instruments of pain and torture. The bundle is then either placed near the effigy or wrapped around it, with most informants claiming the second to be the case. These consecutive wrappings contain unequivocal references to the enclosing of corpses in white cotton shrouds. While reciting a specific duwene [spell, Madurese], the sorcerer goes to immerse the effigy in a large bowl containing the blood of a polos [of one colour; molos, Madurese] chicken that the client has provided. That it is polos is of central importance here. According to the Indonesian dictionary, polos also means 'smooth', 'plain', 'straightforward' or 'without guile' (Echols and Shadily, 1989). Wikan (1987, p 345) notes that in Balinese, a language that is related both to Javanese and Madurese, polos is used extensively to connote socially praiseworthy behaviour, in the sense that a polos person observes the intricate code of etiquette, is capable of controlling negative feelings towards others, and of acting in a selfeffacing and considerate way, being polite and helpful. Although none of my informants offered any explanations as to the significance of polos, I suggest here that the sacrifice of a 'smooth' chicken by the sorcerer heralds the annulment of the contractual masculinity of the groom-victim, in the sense that it removes violently the agency that male persons should display in their everyday dealings. In other words, the slaying of a polos chicken cancels the control the groom-victim exercises over his conduct, a control that is, as we have already seen, a highly masculine attribute.

If my interpretation thus far is correct, the annihilation of the groom's masculinity must be accompanied by the evincing of its femininity. Indeed, the immersion of the effigy in the bowl seems to me to be 


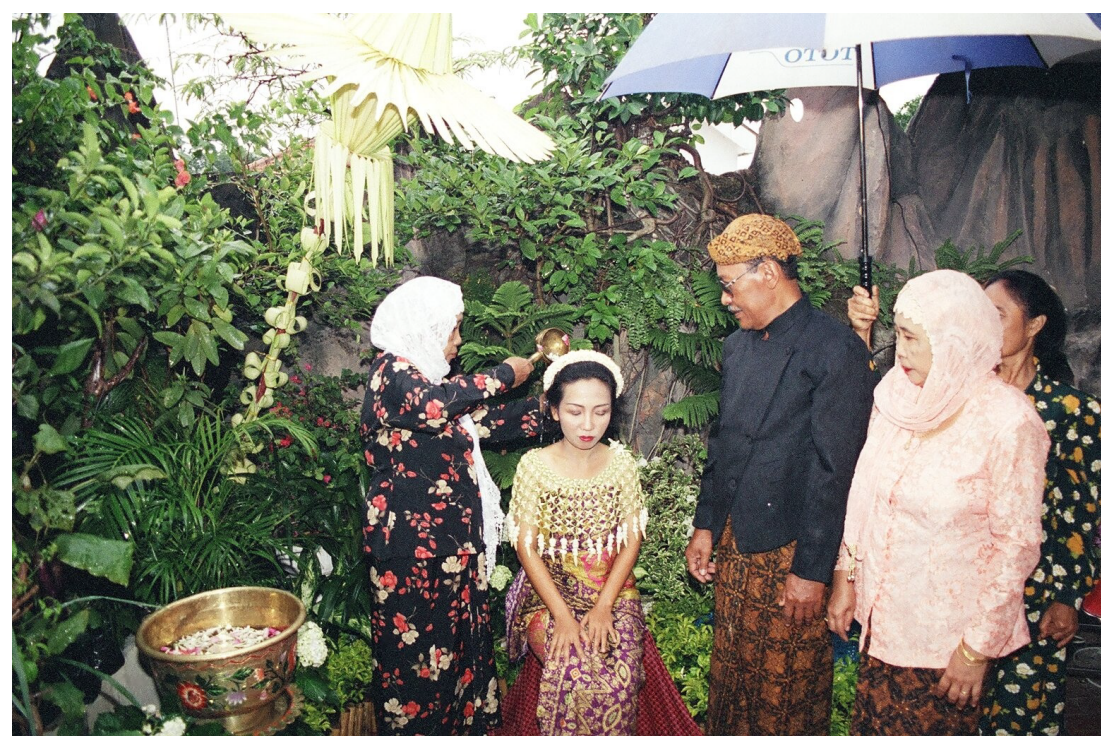

Figure 3. Purifying the bride.

imitating and inverting the purification in a ritual bath known as siraman (Javanese), which the bride undergoes the day before her marriage (see Figure 3). This ritual bath is performed by the bride's parents and other senior female relatives behind the bride's parents' house, using water mixed with the petals of the three kinds of flowers described above. The bath is accompanied by the bestowal of blessings [doa restu] carried by the water on to the bride's body (Koentjaraningrat, 1989, pp 128-129). The sorcerer's spell is structurally equivalent to these blessings, while the substitution of water with blood achieves the instantiation and spread of pollution. The transformation of a victim's masculinity into femininity is therefore evinced through the effigy's forced menstruation, an act that follows on from the cancelling of its control over its bodily functions.

Next, the sorcerer supposedly unties the bundle with the sharp and rusty objects and inserts [masok, Madurese] them into the effigy. The objects' sharpness qualifies them as death instruments, a power that is augmented by the presence of blood and the spell. ${ }^{10}$ Due to it being

10 All of my dukun informants denied possessing sorcery spells. 
penetrated violently, the effigy's femininity is further manifested. The effigy's body is made open and vulnerable, affective and responsive to outside influences. Informants pointed out that the sorcerer is particularly intent on penetrating the effigy's navel [bujhel, Madurese]. The navel sits at the centre of tabu' (Madurese) that stretches from the stomach to the genitals, inclusive of the womb and the hati [heart/liver]. The hati is the most important of the human organs, for it is the centre of cognition and emotion, as well as of the production (by the liver) of blood (see Retsikas, 2007a). A newborn baby has its umbilical cord tied with a thread and its navel wrapped in a cotton shroud that contains a mixture of kitchen ashes, salt and tamarind. When ill, an individual is particularly attentive to his or her navel - which is always treated, whatever the specific symptoms of the illness might be, through rubbing it with kerosene.

The insertion of the sharp objects unties the navel, achieving the regression of the victim into the state of a newborn baby, a state of immense vulnerability and lack of agency. Alternatively, the penetration of the effigy might be construed as an instruction given to the evil spirit on what it is expected to do (see Endicott, 1970, p 174). If the manipulation of the effigy by the sorcerer was held to be sufficiently efficacious by itself, there would be no reason to summon an evil spirit and induce it to marry the victim. The insertion of the instruments of pain and death must be, therefore, a call to the spirit to perform an act of imitation, and aggressively seek to penetrate the bride, acting as masculine persons do. This interpretation is supported by common talk about sorcery that describes it as an arrow made of fire, often seen crossing the night sky over villages. In this regard, the sharp objects and the arrow, intent as it is on finding its target, are equivalent to the spirit's penis, which is set to violate the bride, impregnating her with her own death.

The difference between blessed marriages and sorcery-induced ones does not rest on any qualitative difference between the sexual acts that consummate both types; in either case, sex involves death. However, in the case of the former, death is deemed as essential in the reproduction of life. In the latter, it signals its abrupt end. It is no coincidence that both consummations are socially marked by overgrown bellies, for among the most common symptoms of sorcery affliction is a swollen tabu', as well as blood-spitting and mud-vomiting. The swollen belly is commonly attributed to the placement of sharp and rusty objects into the victim's hati by the evil spirit, something that causes the hati to 
malfunction because of the spread of pollution and deadly words. Counter-sorcery rituals [kalocotan, Madurese, denoting release, separation, freedom - meanings that are of course closely related to divorce) that I have observed focus on locating such objects in the victim's body. In this context, healing consists of attempts at either dissolving such objects through an application of counter-spells and herbal remedies, or extracting them violently, with the dukun often presenting material proof to those witnessing the ritual (Retsikas, 2003, pp 144-148). In the latter case, such proof - nails, broken mirrors and rusty chains - can be and is sometimes returned to the sender.

Alternatively, penetration involves the placement of polluting objects not in the victim's body, but in or next to the victim's house. It is often the case that $d u k u n$ recover nails, broken mirrors and rusty chains from inside pillows, mattresses or chairs, underneath kitchen hearths and inside house walls. These are the places the sorcery arrow has hit. While death is unlikely to occur from this kind of contagion, serious illness is considered a certainty as the intended victim comes into contact with pollution when it is at its most vulnerable: that is, when sleeping, relaxing and digesting food cooked in the family hearth.

\section{Conclusion}

Substantial or essential gender forms have been critiqued in a variety of ways. Butler's critique proposes the concept of performativity that accounts for gender as tenuously accomplished through 'a stylized repetition of acts' (1990, p 140), themselves undertaken within the confines of regulatory discourses concerning the natural and the morally appropriate. In this scheme of analysis, gendered subjects emerge out of processes of consensual subjugation. They are both the product and the means through which subjugation works. However, the ethnographic material presented in this article speaks of different sorts of gender-becoming. This becoming is without determined and definite subjects, for importance is placed not on subject formation, but on transformations, oscillations and metamorphoses. It is not that gendered subjects in Java appear as equally temporal, temporary and incomplete as in other places of the world, but mainly that the transformability of gender forms occupies centre stage.

The implications of the emphasis on transformation can be further elucidated through reference to the radical epistemology Deleuze and Guattari propose in the second part of their philosophical project 
entitled Capitalism and Schizophrenia. Writing against both evolutionism and structuralism, they propose a conceptualization of relationships between terms, parts, forms, etc - as becoming. They argue that:

'A becoming produces nothing other than itself. What is real is the becoming itself, [...] not the supposedly fixed terms through which that which becomes passes. [. . .] a becoming lacks a subject distinct from itself; [...] it has no term, since its term in turn exists only as taken up in another becoming of which it is the subject, and which co-exists with the first.' (1987, p 262)

If singular gender forms are the momentary apparitions of personhood that becoming effects in a never-ending process of motility that involves the other as a fundamental eliciting presence, then we can also think of becoming as facilitated and made possible by two further premises that the ethnography of the intersections of sorcery and gender in Java helps makes explicit. The first premise relates to the oscillation between male and female forms, with oscillation being a particular case of becoming rather than a general type. Oscillation makes for an interesting definition of relationships, for it invites us to think of the process in question as involving forms that are not contrary or opposite - man becoming woman, human becoming animal, and vice versa - but modifications of each other. In our ethnographic example, male and female are transmutations that are part of one another, containing within themselves their own 'antithesis', subsisting and inhering in each other, joined at their borders, coming together at the level of androgyny. That this is so in a society that, according to Errington, 'institutionalises unity but is haunted by duality' (1987, p 435) should be no surprise. The point I am making though is less about sociological typologies and more about epistemology. Oscillation requires the conceptualization of forms as reversible transmutations, and demands the re-inscription of antithesis as difference-in-identity. This re-inscription is embedded within the East Javanese conception of androgyny as an unstable, heterogeneous one-ness, constantly torn apart by its very components. The reality of androgyny is partly inferred, induced and concluded from gender transformations.

To every relationship of parts as modifications of each other, as well as to every process of becoming, there corresponds the application of a degree of power. This is the second premise highlighted by the operation of sorcery as the necessary violence that sets becoming in 
motion. In Java, sorcery is conceived of as an exchange, involving and building upon marital transactions. The violence that pertains in exchanges is readily acknowledged by Strathern, who writes:

'In ceremonial exchange, what looks like the recipients' coercion to attract wealth to themselves is also the coercion on the donor's part. The recipients, having been donors previously, are now the passive cause (the debt) of the newly activated exchange. Activation extracts from them admission of the donor's prestige. They are forced to accept the donor's gifts, acknowledging the debt they created in the past, thereby making themselves for the present inactive.' (1988, p 223)

The medium that registers this violent reversibility in the forms of donor and debtor is the passing of the gift. Similarly, in Java, the gift of mahar and the bestowal of blessings are key moments in the oscillation of gendered forms. To the extent that relationships of exchange necessitate the application of extractive strategies, violence appears as the necessary condition for becoming. Seen from this perspective, the sociality of convivial intimacy is the twin of the sociality of symbolic predation, in the sense that they call each other forth, while simultaneously denouncing each other, suppressing their identity-in-difference. In other words, becoming kin and becoming enemy are not only manifestations of the same oscillatory process, occupying the twin limits of the potentialities of social life, but both rest on the exercise of violence for the evincing of fleeting moments of singularity.

\section{References}

Anderson, B. (1972), 'The idea of power in Javanese culture', in Holt, C., Anderson, B., and Siegel, J., eds, Culture and Politics in Indonesia, Cornell University Press, Ithaca, New York, pp 1-69.

Beatty, A. (1999), Varieties of Javanese Religion: An Anthropological Account, Cambridge University Press, Cambridge.

Beatty, A. (2002), 'Changing places: relatives and relativism in Java', Journal of the Royal Anthropological Institute (NS), Vol 8, No 3, pp 469-491.

Boddy, J. (1982), 'Womb as oasis: the symbolic context of pharaonic circumcision in rural northern Sudan', American Ethnologist, Vol 9, No 4, pp 682-698.

Boellstorff, T. (2004), 'Playing back the nation: waria, Indonesian transvestites', Cultural Anthropology, Vol 19, No 2, pp 159-195.

Boellstorff, T. (2007), A Coincidence of Desires: Anthropology, Queer Studies, Indonesia, Duke University Press, Durham, NC.

Brenner, S. (1998), The Domestication of Desire: Women, Wealth, and Modernity in Java, Princeton University Press, Princeton, NJ. 
Butler, J. (1990), Gender Trouble: Feminism and the Subversion of Identity, Routledge, London.

Carsten, J. (1997), The Heat of the Hearth: The Process of Kinship in a Malay Fishing Community, Clarendon Press, Oxford.

Comaroff, J., and Comaroff, J., eds (1993), 'Introduction', in Modernity and its Malcontents: Ritual and Power in Postcolonial Africa, Chicago University Press, Chicago, IL, pp xi-xxxvii.

Deleuze, G., and Guattari, F. (1987), A Thousand Plateaus: Capitalism and Schizophrenia, Continuum, London.

Djajadiningrat-Nieuwenhuis, M. (1992), 'Ibuism and priyayization: path to power?' in Locher-Scholten, A., and Niehof, A., eds, Indonesian Women in Focus: Past and Present Notions, KITLV Press, Leiden, pp 43-51.

Douglas, M. (1966), Purity and Danger: An Analysis of Concepts of Pollution and Taboo, Routledge \& Kegan Paul, London.

Echols, J., and Shadily, H. (1989), An Indonesian-English Dictionary, Cornell University Press, Ithaca, New York.

Ellen, R. (1993), 'Introduction', in Watson, C. W., and Ellen, R., eds, Understanding Witchcraft and Sorcery in Southeast Asia, University of Hawaii Press, Honolulu, pp $1-25$.

Endicott, K. (1970), An Analysis of Malay Magic, Clarendon Press, Oxford.

Errington, S. (1987), 'Incestous twins and the house societies of insular Southeast Asia', Cultural Anthropology, Vol 2, No 4, pp 403-444.

Errington, S. (1990), 'Recasting sex, gender, and power: a theoretical and regional overview', in Atkinson, J. M., and Errington, S., eds, Power and Difference: Gender in Island Southeast Asia, Stanford University Press, Stanford, CA, pp 1-58.

Florida, N. (1996), 'Sex wars: writing gender relations in nineteenth-century Java', in Spears, L. S., ed, Fantasizing the Feminine in Indonesia, Duke University Press, Durham, NC, pp 207-224.

Geertz, C. (1960), The Religion of Java, University of Chicago Press, Chicago, IL.

Gluckman, M. (1956), Custom and Conflict in Africa, Blackwell, Oxford.

Hoskins, J. (2002), 'The menstrual hat and the witch's lair in two eastern Indonesian societies', Ethnology, Vol 41, No 4, pp 317-333.

Howell, S. (1995), 'Many contexts, many meanings: gendered values among the Northern Lio of Flores, Indonesia', Journal of the Royal Anthropological Institute (NS), Vol 2, No 2, pp 253-269.

Ida, R. (2005), Sunat, Belenggu Adat Perempuan Madura, Universitas Gadjah Mada, Yogyakarta.

Jordaan, R. (1985), 'Folk medicine in Madura (Indonesia)', PhD thesis, University of Leiden, Leiden.

Kapferer, B. (1997), The Feast of the Sorcerer: Practices of Consciousness and Power, University of Chicago Press, Chicago, IL.

Keeler, W. (1987), Javanese Shadow Plays, Javanese Selves, Princeton University Press, Princeton, NJ.

Koentjaraningrat (1989), Javanese Culture, Oxford University Press, Oxford.

Moore, H. (1994), A Passion for Difference: Essays on Anthropology and Gender, Polity Press, Cambridge.

Nabokov, I. (2000), 'Deadly power: a funeral to counter sorcery in South India', American Ethnologist, Vol 27, No 1, pp 147-168.

Newberry, J. (2007), 'Rituals of rule in the administered community: the Javanese slametan reconsidered', Modern Asian Studies, Vol 41, No 6, pp 1295-1329.

Niehof, A. (1992), 'Madurese women as brides and wives', in Locher-Scholten, A., and Niehof, A., eds, Indonesian Women in Focus: Past and Present Notions, KITLV Press, Leiden, pp 166-180. 
Oetomo, D. (1996), 'Gender and sexual orientation in Indonesia', in Spears, L. S., ed, Fantasizing the Feminine in Indonesia, Duke University Press, Durham, NC, pp 259269.

Ong, A. (1989), 'Center, periphery and hierarchy: gender in Southeast Asia', in Morgen, S., ed, Gender and Anthropology: Critical Reviews for Research and Teaching, American Anthropological Association, Washington, DC, pp 294-312.

Osella, C., and Osella, F. (1999), 'Seepage of divinised power through social, spiritual and bodily boundaries', Purusartha - La Possession en Asie du Sud: Parole Corps Territoire, Vol 21, pp 183-210.

Overring, J., and Passes, A., eds (2000), 'Introduction: Convivial intimacy and the opening up of Amazonian anthropology', in The Anthropology of Love and Anger: The Aesthetics of Conviviality in Native Amazonia, Routledge, London, pp 1-30.

Peletz, M. (1993), 'Knowledge, power, and personal misfortune in a Malay context', in Ellen, R., and Watson, C. W., eds, Understanding Witchcraft and Sorcery in Southeast Asia, University of Hawaii Press, Honolulu, pp 149-178.

Peletz, M. (1996), Reason and Passion: Representations of Gender in a Malay Society, University of California Press, Berkeley, CA.

Peluso, N., and Harwell, E. (2001), 'Territory, custom, and the cultural politics of ethnic war in West Kalimantan Indonesia', in Peluso, N. L., and Watts, M., eds, Violent Environments, Cornell University Press, Ithaca, NY, pp 83-116.

Pemberton, J. (1994), On the Subject of 'Java', Cornell University Press, Ithaca, NY.

Rajah, A. (2005), 'Political assassination by other means: public protest, sorcery, and morality in Thailand', Journal of Southeast Asian Studies, Vol 36, No 1, pp 111129.

Retsikas, K. (2003), 'People of mixed blood: ethnicity, personhood, and sociality in East Java, Indonesia', PhD thesis, University of Edinburgh.

Retsikas, K. (2006), 'The semiotics of violence: ninja, sorcerers, and state terror in postSoeharto Indonesia', Bijdragen tot de Taal-, Land-en Volkenkunde (BKI), Vol 162, No 1, pp 56-94.

Retsikas, K. (2007a), 'The power of the senses: ethnicity, history, and embodiment in East Java, Indonesia', Indonesia and the Malay World, Vol 35, No 102, pp 183-210.

Retsikas, K. (2007b), 'Being and place: movement, ancestors, and personhood in East Java, Indonesia', Journal of the Royal Anthropological Institute, Vol 13, No 4, pp 969-986.

Retsikas, K. (2008), 'Becoming sacred: revelation and agency in East Java, Indonesia', paper presented at the 2008 European Association of Social Anthropologists, Ljubljana.

Ross, L. (2005), 'Mask, gender, and performance in Indonesia: an interview with Didik Nini Thowok', Asian Theatre Journal, Vol 22, No 2, pp 214-226.

Santos-Granero, F. (2007), 'Of fear and friendship: Amazonian sociality beyond kinship and affinity', Journal of the Royal Anthropological Institute (NS), Vol 13, No 1, pp $1-18$.

Siegel, J. (2006), Naming the Witch, Stanford University Press, Stanford, CA.

Soedarsono (1969), 'Classical Javanese dance: history and characterisation', Ethnomusicology, Vol 13, No 3, pp 498-506.

Spies, O. (2007), in Bearman, P., et al, 'Mahr', Encyclopaedia of Islam, Brill Online, SOAS, Website: http://www.brillonline.nl/subscriber/entry?entry=islam_SIM-4806 (accessed 19 July 2007).

Strathern, M. (1988), The Gender of the Gift: Problems with Women and Problems with Society in Melanesia, University of California Press, Berkeley, CA.

Sullivan, N. (1994), Masters and Managers: A Study of Gender Relations in Urban Java, Allen \& Unwin, St. Leonards, NSW.

Thomas, M. (2000), The Trouble with Normal: Sex, Politics, and the Ethics of Queer Life, Harvard University Press, Cambridge, MA. 
Turner, V. (1957), Schism and Continuity in an African Society, Manchester University Press, Manchester.

Viveiros de Castro, E. (1996), 'Images of nature and society in Amazonian ethnology', Annual Review of Anthropology, Vol 25, pp 179-200.

Warner, M. (2000), The Trouble with Normal: Sex, Politics, and the Ethics of Queer Life, Harvard University Press, Cambridge, MA.

Wessing, R. (1996), 'Rumours of sorcery at an Indonesian university', Journal of Southeast Asian Studies, Vol 27, No 2, pp 261-279.

Wikan, U. (1987), 'Public grace and private fears: gaiety, offence, and sorcery in northern Bali', Ethos, Vol 15, No 4, pp 337-365.

Wilson, I. (2007), 'Reog Ponorogo: spirituality, sexuality, and power in a Javanese performance tradition', Intersections: Gender, History, and Culture in the Asian Context, Vol 2 (electronic journal), Website: http://wwwsshe.murdoch.edu.au/ intersections/issue2/Warok.html (accessed 3 July 2007).

Woodward, M. (1989), Islam in Java: Normative Piety and Mysticism in the Sultanate of Yogyakarta, University of Arizona Press, Tuscon, AZ. 